Original Articles

\title{
A new ecological risk assessment index for metal elements in sediments based on receptor model, speciation, and toxicity coefficient by taking the Nansihu Lake as an example
}

\author{
Wen Zhuang ${ }^{\mathrm{a}, \mathrm{c}, *}$, Qian Wang ${ }^{\mathrm{a}, *}$, Lebin Tang ${ }^{\mathrm{a}}$, Jinhu Liu ${ }^{\mathrm{a}}$, Wen Yue ${ }^{\mathrm{a}}$, Yongxia Liu ${ }^{\mathrm{a}}$, Fengxia Zhou ${ }^{\mathrm{d}}$, \\ Qing Chen ${ }^{\mathrm{b}}$, Mantang Wang ${ }^{\mathrm{a}, *}$ \\ ${ }^{a}$ Research Center for Aquatic Ecological Environment, College of City and Architecture Engineering, Zaozhuang University, Zaozhuang, Shandong 277160, China \\ ${ }^{\mathrm{b}}$ College of Life Sciences, Zaozhuang University, Zaozhuang, Shandong 277160, China \\ ${ }^{\mathrm{c}}$ Key Laboratory of Coastal Environmental Processes and Ecological Remediation, Yantai Institute of Coastal Zone Research, Chinese Academy of Sciences, Yantai, \\ Shandong 264003, China \\ d Guangdong Province Key Laboratory for Coastal Ocean Variation and Disaster Prediction Technologies, Guangdong Ocean University, Zhanjiang, Guangdong 524088, \\ China
}

\section{A R T I C L E I N F O}

\section{Keywords:}

New index

Metal

Sediment

Ecological risk

The Nansihu Lake

\begin{abstract}
A B S T R A C T
This study focuses on the establishment of a new ecological risk assessment method called as multiparameter evaluation index (MPE) by a combination of speciation, toxicity coefficient, and receptor model of metal elements in sediments and the application of MPE in the assessment of ecological risks of Be, $\mathrm{Sb}$, and $\mathrm{Tl}$ in the Nansihu Lake. Because of lack of toxicity coefficient values for Be, Sb, and $\mathrm{Tl}$, their toxicity coefficients were calculated in this study. Speciation analysis showed that Sb had better mobility and bioavailability than Be and Tl. Source apportionment results showed that Be and Sb were mainly from human activities and introduced minerals. Tl was mainly an inherent mineral. MPE results showed that the degree of ecological risk was $\mathrm{Be}>\mathrm{Sb} \gg \mathrm{Tl}$. MPE could distinguish the ecological risk levels more accurately than current indices such as RI and RAC.
\end{abstract}

\section{Introduction}

Harmful metal elements are usually sparingly biodegradable, but they can accumulate in organisms; expand through food chains; and therefore have long-term, concealed, and hysteretic adverse effects on ecological environment and human health. Metal pollution has been a global concern since many years. The harmful metal content in water significantly increases because of industrial waste discharge, fossil fuel combustion, domestic sewage, water-borne transport, and agricultural irrigation (Prica et al., 2008; Yang et al., 2012; Zhuang et al., 2016).

Sediments are the sources and sinks of various pollutants in the water body. Various pollutants to the water body are adsorbed deposited onto the sediments; conversely, the pollutants in the sediments are released by combination reaction and redox reaction under the action of animals, plants, microbes, etc., to the water body, resulting in secondary pollution of water environment (Harter, 1968; Ciblin, 1997).

As typical harmful metal elements, Beryllium (Be), antimony (Sb), and thallium ( $\mathrm{Tl}$ ) have bioaccumulation and biomagnification effects and have been listed among 13 preferably restricted metal pollutants in water environment by U.S. Environmental Protection Agency (USEPA, 1979). Be can cause pulmonary granulomatous lesions and lung cancer; thus, it is a harmful substance that causes occupational diseases and environmental pollution (Zhang et al., 2011; Hulo et al., 2016). Sb can cause chronic obstructive lung diseases, cardiovascular diseases, cerebrovascular diseases, and apoplexia, and it is a long-spreading global pollutant (Wu et al., 2008; Zhu et al., 2010; Antoine et al., 2015; Fort et al., 2016). Tl causes cardiovascular diseases and has toxicity similar to that of As (Wappelhorst et al., 2000; Peter and Viraraghavan, 2005).

The geochemical behaviors and environmental risks of heavy metals such as $\mathrm{As}, \mathrm{Cd}, \mathrm{Cr}, \mathrm{Hg}, \mathrm{Ni}, \mathrm{Pb}$, and $\mathrm{Zn}$ have been studied by many researchers, but those of $\mathrm{Be}, \mathrm{Sb}$, and $\mathrm{Tl}$ have been studied by few researchers. $\mathrm{Be}, \mathrm{Sb}$, and $\mathrm{Tl}$ are typical disseminated elements in nature. Despite their broad distribution in the earth's crust, their contents are very low and they are applied not so widely as other metal elements. This may be the reason for their environmental risks not being evaluated by relevant researchers and governmental authorities.

\footnotetext{
* Corresponding authors at: Research Center for Aquatic Ecological Environment, College of City and Architecture Engineering, Zaozhuang University, Zaozhuang, Shandong 277160, China (W. Zhuang).

E-mail addresses: wzhuang@yic.ac.cn (W. Zhuang), lanseqiancao@sina.com (Q. Wang), wangmantang@aliyun.com (M. Wang).
} 


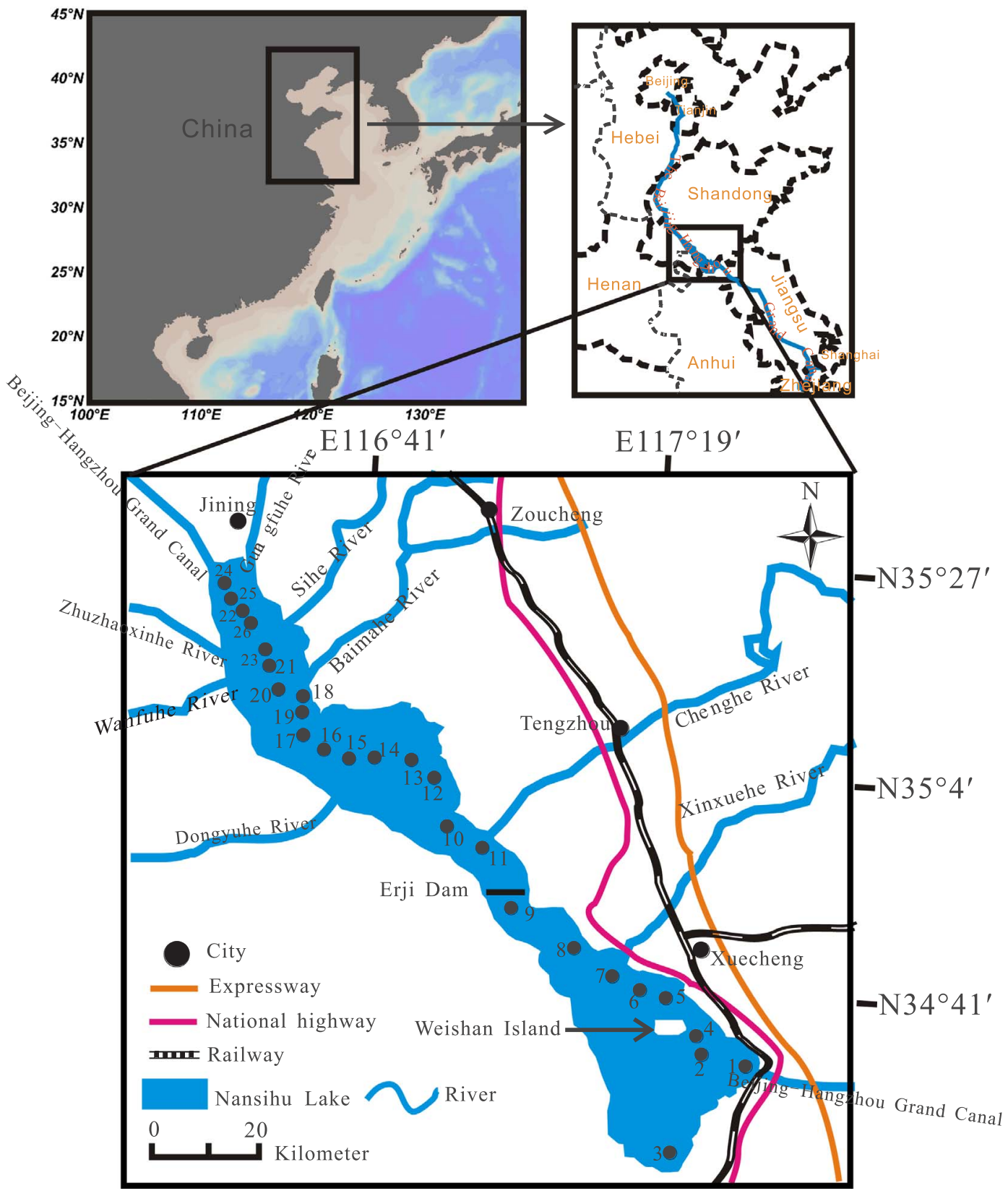

Fig. 1. Location of the sampling sites in the Nansihu Lake.

There are many methods for the assessment of pollution by metal elements in sediments. The basic principle mainly includes the following: (1) Ratio of total metal content to background value, for example, Geoaccumulation index ( $I_{\text {geo }}$, Müller, 1969) and Enrichment factor (EF, Alexander et al., 1993); (2) speciation of metal element, for example, Risk assessment code (RAC;Perin et al., 1985); (3) Håkanson (1980) initially introduced the concept of toxicity coefficient and determined the toxicity coefficient values of several metal elements; the metal with higher toxicity coefficient has higher toxicity. Håkanson established potential ecological risk index (RI). The relationship between total metal content and background value and the toxicity of different metals were considered in this method. However, the speciation of metal elements in sediments was not considered in this method.

The receptor model for absolute principal component scores-multivariate linear regression (APCS-MLR) was proposed by Thurston and Spengler in 1985. The basic principle is that the principal component score for analysis is converted to APCS before MLR of the receptor content. The regression coefficient is used to calculate the contribution of the corresponding emission source of each component to this substance in the receptor (Thurston and Spengler, 1985).

In this paper, an ecological risk assessment index for metal elements in sediments based on the receptor model of APCS-MLR, speciation, and toxicity coefficient was established for the assessment of ecological risks of $\mathrm{Be}, \mathrm{Sb}$, and Tlin surface sediments of the Nansihu Lake as Chinese typical lake. The toxicity coefficient of $\mathrm{Be}, \mathrm{Sb}$, and $\mathrm{Tl}$ has not been determined. Thus, their toxicity coefficient values were calculated first according to the Håkanson calculation principle.

\section{Materials and methods}

\subsection{Studied area and sample collection}

South-to-North Water Diversion Project is a strategic infrastructure to transfer water resources across different regions and also one of the biggest water transfer projects in the world. This project covers ChangJiang River, Huaihe River, Yellow River, and Haihe River in over 
10 provinces. The east route of this project is $1467 \mathrm{~km}$ long and was formally transferred water in November 2013, with a transfer scale of 14.8 billion $\mathrm{m}^{3} / \mathrm{a}$. This project makes important contribution to mitigation of serious water scarcity in Northern China (Zhuang, 2016).

The Nansihu Lake is the sixth largest freshwater lake in China and the biggest natural surface water resource reservoir in Shandong Province. The Nansihu Lake is not only a drive hub in the east route of South-to-North Water Diversion Project but also the largest reservoir lake in the east route. The Nansihu Lake is very important to improve water quality along water transfer lines because it absorbs harmful metals and reduces organic pollutants. Thus, the water quality of the Nansihu Lake is closely associated with not only the ecological system in the lake but also the water safety of the east route of South-to-North Water Diversion Project.

The Nansihu Lake runs from northwest to southeast and consists of Nanyang Lake, Dushan Lake, Zhaoyang Lake, and Weishan Lake without invisible boundary. Its average depth is $1.5 \mathrm{~m}$. The Nansihu Lake belongs to warm temperate and semi-humid monsoon continental climate, with four distinctive seasons, abundant light and heat resources, hot rainy season, an average annual temperature of $13.7^{\circ} \mathrm{C}$, and an average annual precipitation of $700 \mathrm{~mm}$, of which, the summer rainfall accounts for $60 \%-80 \%$ (Lu et al., 2003; Ma et al., 2014). The Nansihu Lake has a wide surface and narrow middle portion, is about $126 \mathrm{~km}$ long from south to north, and about $5-25 \mathrm{~km}$ wide from east to west and covers $1266 \mathrm{~km}^{2}$. The Nansihu Lake receives water from more than 50 rivers with $31,700 \mathrm{~km}^{2}$ drainage area in Shandong, Jiangsu, Henan, and Anhui. In 1960, the Erji Dam was completed in the narrowest part of the Zhaoyang Lake to divide this lake into the upper and lower sections from north to south. The upper and lower sections cover 602 and $664 \mathrm{~km}^{2}$, respectively.

The surface sediments were sampled in April, 2017. Twenty-six sampling sites were provided for the Nansihu Lake (Fig. 1) in the principle that the upper section has more sampling points than the lower section and the sampling points are as close as possible to the industrial park in the northeast bank or lake intake. The lower and upper sections have nine sampling sites, i.e., No. 1-No. 9, and seventeen sampling points, i.e., No. $10-$ No. 26 , respectively. The coordinates of the sites are listed in Appendix 2. The surface sediments were sampled using a stainless steel grab sampler. The well-mixed sample was packed with a PE bag, which is rapidly placed in an insulated box with ice bags. The PE bag was immersed in $10 \% \mathrm{HNO}_{3}(\mathrm{v} / \mathrm{v})$ for over $48 \mathrm{~h}$ in a laboratory before sampling and rinsed with Milli-Q water (Resistivity: not less than $18 \mathrm{M} \Omega * \mathrm{~cm}$ ). The sample was transported to the laboratory and stored at $4^{\circ} \mathrm{C}$.

\subsection{Chemical analysis of the surface sediments}

\subsubsection{Total metal element content analysis}

The sample was frozen and dried by a freeze drier, ground, and selected through a 200 mesh sieve; $0.1000 \pm 0.0010 \mathrm{~g}$ of sample was accurately weighed to PTFE digestion tank and digested using $\mathrm{HNO}_{3}$, $\mathrm{HF}$, and $\mathrm{HClO}_{4}$. See another paper for details (Zhuang et al., 2016). Total $\mathrm{Be}, \mathrm{Sb}$, and $\mathrm{Tl}$ contents were determined using ICP-MS (PerkinElmer, NexION 350D). Al, Fe, and Mn contents were determined using ICP-OES (PerkinElmer, Optima 8000DV).

\subsubsection{Speciation analyses of $\mathrm{Be}, \mathrm{Sb}$, and $\mathrm{Tl}$}

A method invented by the former European Community Bureau of Reference (the BCR method for short) is a common method to distinguish different forms of the metals in the sediments (Rauret et al., 1999). According to the BCR method, the metal elements in the sediments could be divided into the following four forms (Karbassi and Shankar, 2005):

(1) Acid-soluble (including exchangeable and carbonate bound): mainly produced from human activity, with high bioavailability 
and high environmental risk.

(2) Reducible (Fe/Mn oxides or hydrous oxide bound): can be released from the sediments to the water body by reduction, and bioavailable.

(3) Oxidable (organic substance and sulfide bound): can be released to the water body after the combined organic substances are decomposed into inorganic substances in oxidizing environment.

(4) Residual: inert components of metal elements in the sediments, mainly mineral facies, bound in the crystal lattices of the sediments, from nature, and barely biologically used.

The operation steps of BCR are shown in Table 1 (Rauret et al., 1999; Gao et al., 2010). Further in this paper, the four chemical forms are briefly named as F1, F2, F3, and F4. The F1, F2, and F3 contents of $\mathrm{Be}, \mathrm{Sb}$, and $\mathrm{Tl}$ were determined by ICP-MS. F4 content was total metal content - (F1 + F2 + F3).

The reference material GBW07437 was used to ensure the accuracy of extraction. Recoveries of all the four chemical forms of $\mathrm{Sb}$ were higher than $87 \%$. However, there is no reference values for $\mathrm{Be}$ and $\mathrm{Tl}$ in GBW07437. To inspect the accuracy of the BCR method for Be and Tl, five samples randomly selected after the F3 extraction step were selected for F4 digestion and determination. The results showed that the difference between sum of the measured F1-F4 contents and total measured value did not exceed $15 \%$.

\subsection{Estimation of sediment contamination}

\subsubsection{Risk assessment code (RAC)}

As a common ecological risk evaluation index, RAC was calculated from the formula (Perin et al., 1985):

$\mathrm{RAC}=\mathrm{Exc} \%+\mathrm{Carb} \%$

where Exc\% and Carb\% represent the percentages of exchangeable and carbonate bound, respectively, in total metal content, i.e., F1 in this study. According to RAC, the sediments were categorized into five levels: (1) $\mathrm{RAC} \leq 1 \%$, no risk; (2) $1 \%<\mathrm{RAC} \leq 10 \%$, low risk; (3) $10 \%<$ RAC $\leq 30 \%$, moderate risk; (4) $30 \%<$ RAC $\leq 50 \%$, high risk; (5) $50 \%<$ RAC, very high risk. This method, which was created based on the geochemical form of metal, could reflect the percentage of biologically effective components in total metal content better than total content.

\subsubsection{Potential ecological risk index (RI)}

According to Håkanson's (1980) viewpoint, metals hazard to humans and the aquatic ecosystem include two aspects, i.e., the abundance principle and the release effect. The potential biotoxicity of metal elements is inversely proportional to their abundances. In this research, toxicity coefficients of $\mathrm{Be}, \mathrm{Sb}$, and $\mathrm{Tl}$ were determined considering their rank of relative abundance and the release effect of these elements by using the known toxicity coefficients of $\mathrm{As}, \mathrm{Cd}, \mathrm{Cr}, \mathrm{Cu}, \mathrm{Hg}, \mathrm{Pb}, \mathrm{Zn}$, etc.

$\mathrm{RI}$ included single-factor potential ecological RI $\left(\mathrm{E}_{\mathrm{r}}^{\mathrm{i}}\right)$, and comprehensive potential ecological index $\left(E_{R I}\right) . E_{r}^{i}$ was calculated as shown below (Håkanson, 1980):

$E_{r}^{i}=T_{r}^{i} \times C_{f}^{i}$

$C_{f}^{i}=C_{o}^{i} \div C_{n}^{i}$

where $\mathrm{T}_{\mathrm{r}}{ }^{\mathrm{i}}$ is the toxic response factor of the element $\mathrm{i} ; C_{\mathrm{f}}^{\mathrm{i}}, C_{\mathrm{o}}{ }_{\mathrm{o}}^{\mathrm{i}}$, and $C_{\mathrm{n}}{ }^{\mathrm{i}}$ are the pollution coefficient of element $i$, element $i$ concentration in the sediments, and its environmental background value, respectively. According to $\mathrm{E}_{\mathrm{r}}^{\mathrm{i}}$, the sediments were categorized into five levels: (1) $\mathrm{E}_{\mathrm{r}}{ }^{\mathrm{i}} \leq 40$, low risk; (2) $40<\mathrm{E}_{\mathrm{r}}{ }^{\mathrm{i}} \leq 80$, moderate risk; (3) $80<\mathrm{E}_{\mathrm{r}}{ }^{\mathrm{i}} \leq 160$, moderate to high risk; (4) $160<\mathrm{E}_{\mathrm{r}}{ }^{\mathrm{i}} \leq 320$, high risk; (5) $320<\mathrm{E}_{\mathrm{r}}^{\mathrm{i}}$, very high risk.

$\mathrm{E}_{\mathrm{RI}}$ was calculated as shown below (Håkanson, 1980):
$E_{R I}=\sum_{i}^{n} E_{r}^{i}=\sum_{i}^{n} T_{r}^{i} \times C_{f}^{i}$

According to $\mathrm{E}_{\mathrm{RI}}$, the sediments were categorized into four levels: (1) $\mathrm{E}_{\mathrm{RI}} \leq 150$, low risk; (2) $150<\mathrm{E}_{\mathrm{RI}} \leq 300$, moderate risk; (3) $300<\mathrm{E}_{\mathrm{RI}} \leq 600$, high risk; and (4) $\mathrm{E}_{\mathrm{RI}}>600$, very high risk.

\subsubsection{Multiparameter evaluation index (MPE)}

2.3.3.1. Calculation according to the receptor model for APCS-MLR. The $\mathrm{Be}, \mathrm{Sb}$, and $\mathrm{Tl}$ contents of the samples from all the sampling sites were normalized first before calculation according to the following formulas (Thurston and Spengler, 1985):

(1) An artificial sample with 0 content was introduced, and the component score of 0 content sample was calculated according to the following formula:

$$
Z_{0 i}=\frac{0-\overline{C_{i}}}{\sigma_{i}}=-\frac{\overline{C_{i}}}{\sigma_{i}}
$$

(2) APCS of each element was calculated according to the rotated component score and 0 content artificial sample.

(3) The absolute principal component was used as the independent variable, and the metal element content in each sample was used as the dependent variable for MLR:

$C_{i}=b_{i 0}+\sum_{p=1}^{p}\left(b_{p i} \times A P C S_{p}\right)$

where $\overline{C_{i}}$ is the arithmetic average content of the metal element $i, \sigma_{i}$ is the standard deviation of the content of the element $i, C_{i}$ is the content of the element $i, b_{i 0}$ is the constant term of MLR, $b_{p i}$ is the regression coefficient of MLR, $\mathrm{APCS}_{\mathrm{p}}$ is the absolute principal component score, and $\left(b_{p i} \times\right.$ APCS $\left._{p}\right)$ is the content contribution of the pth principal component (i.e., source p) to $\mathrm{C}_{\mathrm{i}}$.

2.3.3.2. Multiparameter evaluation index analysis. In this paper, an ecological risk assessment index for metal elements in sediments based on receptor model, speciation, and toxicity coefficient was established and referred to as multiparameter evaluation index (MPE), according to the following formula:

$\mathrm{MPE}=T_{r}^{i} \times P_{i} \times \mathrm{NonR}_{i}$

where $T_{r}{ }^{i}$ is the toxic response factor of the element $i$; $P_{i}$ is the contribution rate of principal components (PCs) from human activity to the element $i$; NorR is the content of nonresidual portion of the element i (i.e., contents of F1, F2, and F3).

In general, most metals in the form of $\mathrm{F} 4$ are from natural sources and exist in the form of minerals in nature. F1, F2, and F3 contain the components from both human activities and nature. It is not stringent that only percentage of $\mathrm{F} 1$ is used as the pollution index of metal elements in RAC. Thus, the contribution of the elements from human activities was introduced to MPE as a weight, and the absolute nonresidual metal content replaced the F1 percentage content in RAC. $\mathrm{T}_{\mathrm{r}}{ }^{\mathrm{i}}$ was used to distinguish the biotoxicity of different metal elements. The metal element pollution could not be graded by this index because of lack of relevant biotoxicity test and statistical data. This index was only for reference for research in relevant fields.

\section{Results and discussions}

\subsection{Toxicity coefficient determination for $\mathrm{Be}, \mathrm{Sb}$, and $\mathrm{Tl}$}

Håkanson (1980) proposed that the toxic factor should primarily give information about the potential transport avenues of toxic substances and the threat to human. Secondarily, the toxic factor should 
Table 2

The abundance of element in different matters $(\mu \mathrm{g} / \mathrm{g})$.

\begin{tabular}{llllll}
\hline Element & Igneous rock & Soil & Freshwater & $\begin{array}{l}\text { Terrestrial } \\
\text { plant }\end{array}$ & $\begin{array}{l}\text { Terrestrial } \\
\text { animal }\end{array}$ \\
\hline $\mathrm{As}$ & 1.8 & 6.0 & 0.0004 & 0.2 & 0.2 \\
$\mathrm{Cd}$ & 0.2 & 0.06 & 0.00031 & 0.6 & 0.5 \\
$\mathrm{Cr}$ & 100 & 100 & 0.00018 & 0.23 & 0.075 \\
$\mathrm{Cu}$ & 55 & 20 & 0.01 & 14 & 2.4 \\
$\mathrm{Hg}$ & 0.08 & 0.415 & 0.00008 & 0.015 & 0.046 \\
$\mathrm{~Pb}$ & 12.5 & 10 & 0.005 & 2.7 & 2.0 \\
$\mathrm{Zn}$ & 70 & 50 & 0.01 & 100 & 160 \\
$\mathrm{Be}$ & 3.0 & 1.95 & 0.00019 & 0.05 & 0.01 \\
$\mathrm{Sb}$ & 0.2 & 1 & 0.0002 & 0.05 & 0.1 \\
$\mathrm{Tl}$ & 0.75 & 0.2 & 0.00005 & 0.25 & 0.1 \\
\hline
\end{tabular}

also give information about the even more complex threat to the aquatic ecological system. The main course of contaminants is as follows: water-sediment-biota-fish-human. The potential toxicological effect of an element is proportional to the abundance, or rather the rarity in nature of this element. Håkanson chose igneous rocks, soil, freshwater, land plants, and land animals as representatives of different types of geological and biological media. He also pointed that when reliable data become available from other types of media, especially from the freshwater environment, it would be natural and beneficial to make a revision of the results given in this context (Håkanson, 1980).

Table 2 lists the abundance of $\mathrm{Be}, \mathrm{Sb}, \mathrm{Tl}, \mathrm{As}, \mathrm{Cd}, \mathrm{Cr}, \mathrm{Cu}, \mathrm{Hg}, \mathrm{Pb}$, and $\mathrm{Zn}$ in igneous rock, soil, freshwater, terrestrial plants, and terrestrial animals (Schoer, 1984; Chen et al., 1989; Sun and Dong, 1991; Qi et al., 1992; Slobodan et al., 1993; Cleven and Fokkert, 1994; Taylor and McLennan, 1995; Zhang et al., 1997; Filella et al., 2002; Kenneth et al., 2009; Zhu et al., 2010). Relative abundance of elements having the highest abundance in one media was identified as 1.0. For example, $\mathrm{Cr}$ having the highest abundance in igneous rock was assigned to 1.0; $\mathrm{Cd}$ having 500 times smaller abundance than $\mathrm{Cr}$ was assigned to 500 (Table 3).

Total relative abundance of one element was the sum of relative abundance of the element in all the five media listed in Table 3. The highest value of the five relative abundances of an element was neglected to prevent inappropriate weight of the total relative abundance. The sum of the other four relative abundances was divided by 4.4 (the smallest value of total relative abundance, i.e., value of $\mathrm{Zn}$ ) to obtain the average relative abundance of an element: $\mathrm{Zn}<\mathrm{Cu}<\mathrm{Pb}<$ $\mathrm{Cr}<\mathrm{As}<\mathrm{Cd}<\mathrm{Tl}<\mathrm{Be}<\mathrm{Sb}<\mathrm{Hg}$.

Håkanson (1980) pointed out that the relative abundance of an element was associated with its toxicity coefficient but was not simply equal to its toxicity coefficient. Release effect can indicate sedimentation trends of different metals in sediments. Release effect was calculated using the relative abundance.

Metal release coefficient $=$ Metal background value in
freshwater/Metal background value in sediment before industrialization

The calculated release coefficients of the above metals are listed in Table 4 (Tech, 1986; Mou, 1999; Bai et al., 2004; Xu et al., 2008). The release coefficients of 10 metals in sediments calculated according to this method are listed in an increasing sequence: $\mathrm{Cr}<\mathrm{Tl}<\mathrm{As}<$ $\mathrm{Sb}<\mathrm{Zn}<\mathrm{Be}<\mathrm{Pb}<\mathrm{Cu}<\mathrm{Cd}<\mathrm{Hg}$. For each metal element, its average relative abundance is multiplied by release coefficient to obtain the corrected relative abundance; see Table 4.

The corrected relative abundances of the 10 metals were used to indicate their toxicity coefficients. Elements with higher relative abundance and release coefficient have higher toxicity, i.e., release coefficient was associated with abundance.

In application, the corrected relative abundance of metal elements was divided by 57.5 (corrected relative abundance of $\mathrm{Zn}$, the smallest of the 10 elements) to obtain $\mathrm{As}=62.9, \mathrm{Cd}=1248.5, \mathrm{Cr}=3.9$, $\mathrm{Cu}=11.8, \quad \mathrm{Hg}=6443.3, \quad \mathrm{~Pb}=16.1, \quad \mathrm{Zn}=1.0, \quad \mathrm{Be}=535.0$, $\mathrm{Sb}=355.7$, and $\mathrm{Tl}=42.8$, the square roots of which are extracted and rounded off to the integers, i.e., $\mathrm{As}=8, \mathrm{Cd}=35, \mathrm{Cr}=2, \mathrm{Cu}=3$, $\mathrm{Hg}=80, \mathrm{~Pb}=4, \mathrm{Zn}=1, \mathrm{Be}=23, \mathrm{Sb}=19$, and $\mathrm{Tl}=7$. These are the ultimate values of toxicity coefficients.

The calculation results showed that $\mathrm{Hg}$ had the highest toxicity coefficient, followed by $\mathrm{Cd}, \mathrm{Be}$, and Sb. Toxicity coefficients of $\mathrm{Tl}$ and As were approximate. Håkanson considered the toxicity coefficient of $\mathrm{Hg}$ might be overestimated; hence, the value was halved in practice, i.e., 40. Håkanson determined the toxicity coefficients for As, Cd, Cr, $\mathrm{Cu}, \mathrm{Hg}, \mathrm{Pb}$, and $\mathrm{Zn}$ as 10, 30, 2, 5, 40, 5, and 1, respectively. Slight differences between the toxicity coefficients determined by Håkanson and those in this study could be found; this maybe due to the fact that the abundances of elements in the five media considered in this study were different from the abundances taken by Håkanson. However, the calculated toxicity coefficients were highly consistent. In addition, the toxicity coefficients defined by Håkanson were multiples of 2 or 5; hence, the toxicity coefficients of $\mathrm{Be}, \mathrm{Sb}$, and $\mathrm{Tl}$ were determined as 25 , 20 , and 10 respectively.

\subsection{Spatial distribution characteristics of $B e, S b$, and $T l$}

According to the survey data from the 26 sampling sites, the spatial distribution of $\mathrm{Be}, \mathrm{Sb}$, and $\mathrm{Tl}$ in the surface sediments of the Nansihu Lake was analyzed as shown in Fig. 2. The surface sediments of the Nansihu Lake had average Be, Sb, and Tl contents of 2.89, 1.23, and $0.374 \mu \mathrm{g} / \mathrm{g}$, respectively. In addition, the upper section had a higher average Be content but lower average $\mathrm{Sb}$ and $\mathrm{Tl}$ contents of the surface sediments than those in the lower section, indicating that they came from different sources. On the basis of the spatial variability characteristics, Be, Sb, and $\mathrm{Tl}$ variability coefficients were very small, $13.27 \%, 17.14 \%$, and $14.63 \%$, respectively, indicating that the three elements distributed uniformly in the surface sediments of the Nansihu

Table 3

The relative abundance of elements in different matters.

\begin{tabular}{|c|c|c|c|c|c|c|c|}
\hline Element & Igneous rock & Soil & Freshwater & Terrestrial plant & Terrestrial animal & $\sum_{i=1}^{4}$ & Average relative abundance \\
\hline As & 55.6 & 16.7 & 25.0 & 500.0 & 800.0 & 597.2 & 135.7 \\
\hline $\mathrm{Cd}$ & 500.0 & 1666.7 & 32.3 & 166.7 & 320.0 & 1018.9 & 231.6 \\
\hline $\mathrm{Cr}$ & 1.0 & 1.0 & 55.6 & 434.8 & 2133.3 & 492.3 & 111.9 \\
\hline $\mathrm{Cu}$ & 1.8 & 5.0 & 1.0 & 7.1 & 66.7 & 15.0 & 3.4 \\
\hline $\mathrm{Hg}$ & 1250.0 & 241.0 & 125.0 & 6666.7 & 3478.3 & 5094.2 & 1157.8 \\
\hline $\mathrm{Pb}$ & 8.0 & 10.0 & 2.0 & 37.0 & 80.0 & 57.0 & 13.0 \\
\hline $\mathrm{Zn}$ & 1.4 & 2.0 & 1.0 & 1.0 & 1.0 & 4.4 & 1.0 \\
\hline $\mathrm{Be}$ & 33.3 & 51.3 & 52.6 & 2000.0 & 16000.0 & 2137.2 & 485.7 \\
\hline $\mathrm{Sb}$ & 500.0 & 100.0 & 50.0 & 2000.0 & 1600.0 & 2250.0 & 511.4 \\
\hline $\mathrm{Tl}$ & 133.3 & 500.0 & 200.0 & 400.0 & 1600.0 & 1233.3 & 300.5 \\
\hline
\end{tabular}

$\sum_{i=1}^{4}$ is the sum of four items after removal of the highest abundant element in igneous rock, soil, freshwater, terrestrial plants, and terrestrial animals. 
Table 4

The release coefficient of elements.

\begin{tabular}{|c|c|c|c|c|c|}
\hline Element & $\begin{array}{l}\text { Background value in freshwater } \\
(\mu \mathrm{g} / \mathrm{g})\end{array}$ & $\begin{array}{l}\text { Content in lacustrine sediments before } \\
\text { industrialization }(\mu \mathrm{g} / \mathrm{g})\end{array}$ & $\begin{array}{l}\text { Release coefficient } \\
\left(\times 10^{-6}\right)\end{array}$ & $\begin{array}{l}\text { Average relative } \\
\text { abundance }\end{array}$ & $\begin{array}{l}\text { Corrected relative } \\
\text { abundance }\end{array}$ \\
\hline As & 0.0004 & 15 & 26.7 & 135.7 & 3619.5 \\
\hline $\mathrm{Cd}$ & 0.00031 & 1 & 310.0 & 231.6 & 71787.9 \\
\hline $\mathrm{Cr}$ & 0.00018 & 90 & 2.0 & 111.9 & 223.8 \\
\hline $\mathrm{Cu}$ & 0.01 & 50 & 200.0 & 3.4 & 680.0 \\
\hline $\mathrm{Hg}$ & 0.00008 & 0.25 & 320.0 & 1157.8 & 370489.1 \\
\hline $\mathrm{Pb}$ & 0.005 & 70 & 71.4 & 13.0 & 925.9 \\
\hline $\mathrm{Zn}$ & 0.01 & 175 & 57.1 & 1.0 & 57.5 \\
\hline $\mathrm{Be}$ & 0.00019 & 3 & 63.3 & 485.7 & 30763.4 \\
\hline $\mathrm{Sb}$ & 0.0002 & 5 & 40.0 & 511.4 & 20454.5 \\
\hline $\mathrm{Tl}$ & 0.00005 & 5.7 & 8.8 & 280.3 & 2458.8 \\
\hline
\end{tabular}

Lake.

Maximum Be content of $3.38 \mu \mathrm{g} / \mathrm{g}$ occurred at Site 24, which was in the farthest north and very close to Jining City Industry Park; maximum Sb content of $1.77 \mu \mathrm{g} / \mathrm{g}$ occurred near the mouth of Beijing-Hangzhou Canal; maximum $\mathrm{Tl}$ content of $0.506 \mu \mathrm{g} / \mathrm{g}$ occurred near the ship lock at the culture area, showing that human activity made significant contribution to the three elements in the sediments.

There was lack of environmental background value of sediments containing Be, Sb, and $\mathrm{Tl}$ in the Nansihu Lake. However, the Nansihu Lake was the former place where ancient Sishui flowed through. In the 12th century, Yellow River trespassed southward Sishui waterway, resulting in unobstructed drain and leading to the formation of a lake (Guo, 1990). The background values of the Yellow River sediments proposed by Zhao and Yan (1992) are mostly used in the study of the heavy metals in the sediments of the Nansihu Lake (Yang et al., 2003; Li and Zhang, 2012). The samples of the Yellow River sediments collected by Zhao and Yan (1992) were from Zhengzhou, Pingyin, Jinan, and Binzhou, the latter three cities are all in Shandong Province and closest to the study area. Thus, Be, Sb, and $\mathrm{Tl}$ contents of the sediments of the Yellow River were selected as the environmental background values in this study (Guo, 1990; Dong, 2009; Zhuang et al., 2016).

The Be, Sb, and $\mathrm{Tl}$ background contents of the sediments of the Yellow River were 1.7, 0.62, and $0.45 \mu \mathrm{g} / \mathrm{g}$, respectively (Zhao and Yan, 1992). The average Be and Sb contents of the sediments of the Nansihu Lake were higher but with a slightly lower average $\mathrm{Tl}$ content than the corresponding environmental background value in the sediments of the Yellow River.
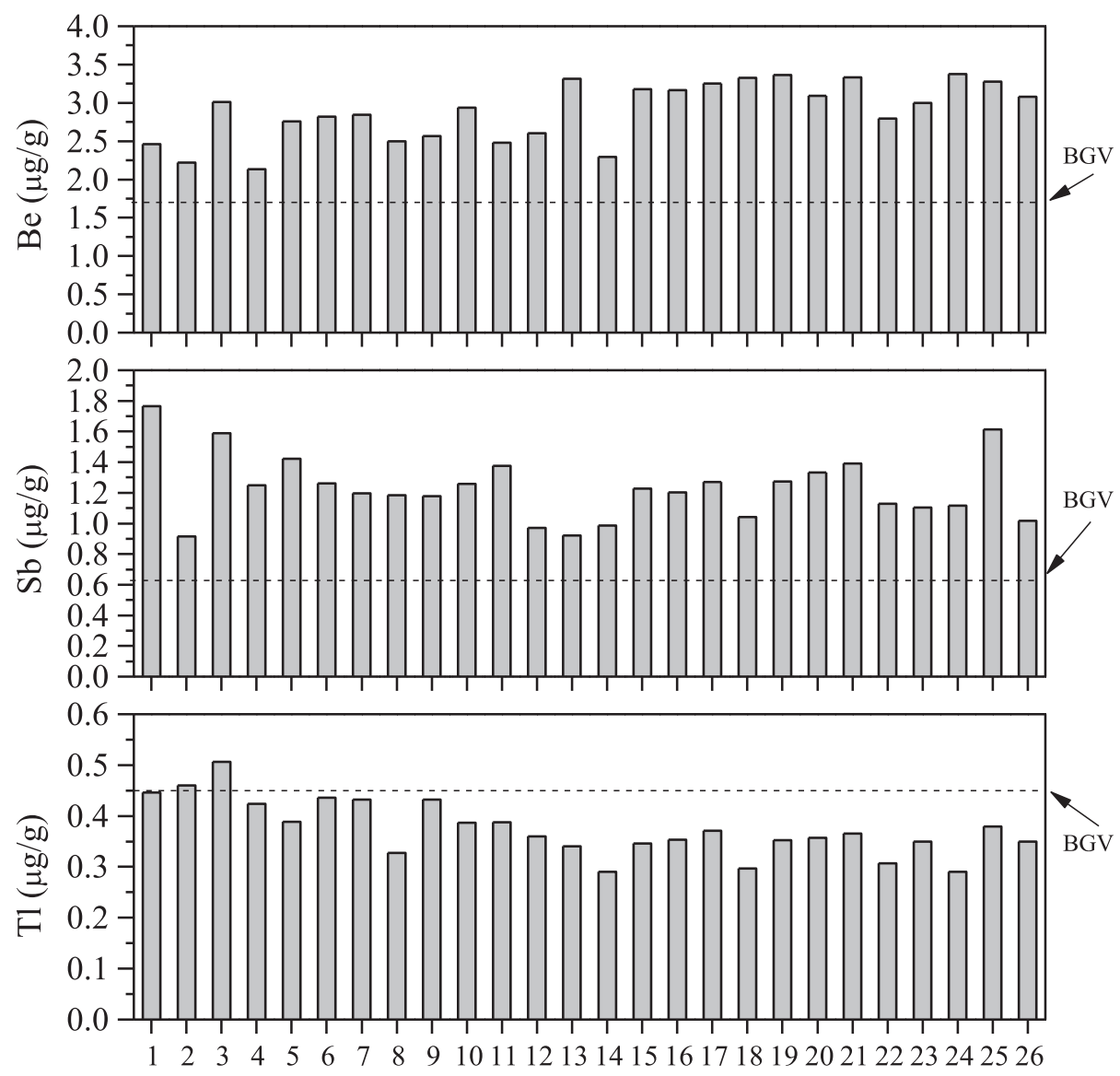

Site ID

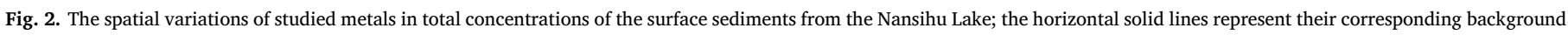
values (BGVs). 

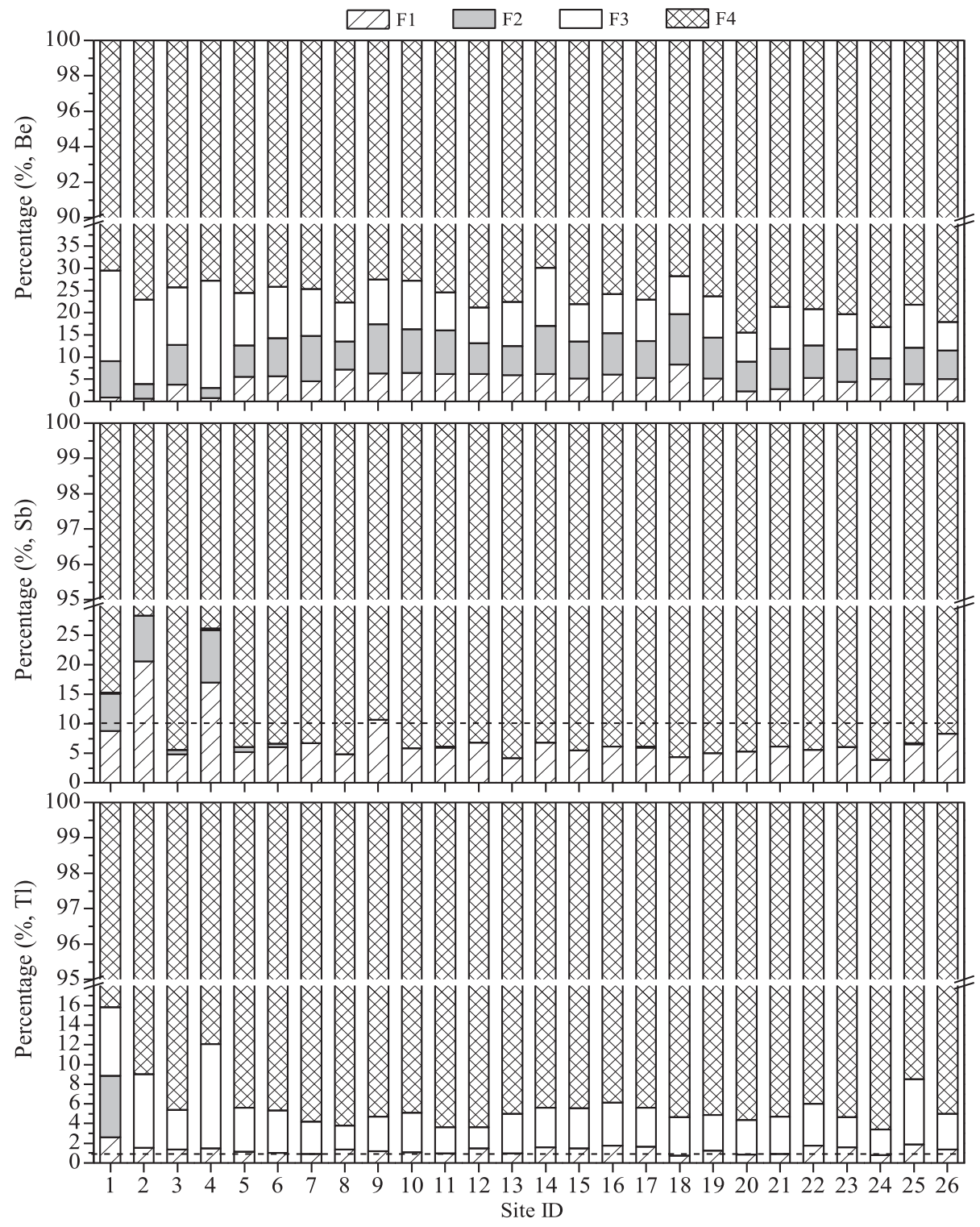

Fig. 3. The distributions of geochemical phases and RAC values for the studied metals in the surface sediments.

\section{3. $\mathrm{Be}, \mathrm{Sb}$, and $\mathrm{Tl}$ speciation characteristics}

The toxicity and bioavailability of the metal elements in the sediments depended on their chemical forms in the sediments; hence, the study on the form characteristics of metal elements reflected better their environmental effects. The distribution of $\mathrm{Be}, \mathrm{Sb}$, and $\mathrm{Tl}$ forms in the surface sediments is shown in Fig. 3. Most sediments from the sampling sites had the same $\mathrm{Be}, \mathrm{Sb}$, and $\mathrm{Tl}$ forms. The percentage of $\mathrm{F} 4$ of the three elements was the highest, over $65 \%, 70 \%$, and $84 \%$, respectively, showing that they mainly originated from minerals. The percentages of various $\mathrm{Be}, \mathrm{Sb}$, and $\mathrm{Tl}$ forms were in the following descending sequences: $\mathrm{F} 4>\mathrm{F} 3>\mathrm{F} 2>\mathrm{F} 1, \mathrm{~F} 4>\mathrm{F} 1>\mathrm{F} 2>\mathrm{F} 3$ and F4 $>$ F3 $>$ F1 $>$ F3.

The samples from Sites 1, 2, and 4 had much higher nonresidual Sb and $\mathrm{Tl}(\mathrm{F} 1+\mathrm{F} 2+\mathrm{F} 3)$ contents than those from other sampling sites. Site 1 was located at lake mouth of Beijing-Hangzhou Canal, and Sites 2 and 4 were close to Beijing-Hangzhou Canal, which was the main waterway in the east route of South-to-North Water Diversion Project. Thus, nonresidual $\mathrm{Sb}$ and $\mathrm{Tl}$ in the sediments from Sites 1, 2, and 4 would have mainly come from the South-to-North Water Diversion Project.
The average $\mathrm{F} 1$ content of Be was about $4.8 \%$, and the average F2 and $\mathrm{F} 3$ contents were $7.82 \%$ and $10.78 \%$, respectively, with small difference in form content between the sampling sites. Except for F4, the $\mathrm{F} 1$ content of $\mathrm{Sb}$ was the highest, $7 \%$ of total content on average, whereas F2 and F3 contents were negligible, showing that Sb was significantly influenced by human activity, and Sb combined the sediments so weakly as to readily return to the water body resulting in secondary pollution. Average F1 content of $\mathrm{Tl}$ was only above $1 \%$, resulting in very low bioavailability. In nonresidual Tl, F2 content was almost negligible and F3 content was relatively high. The surface sediments in the studied area had average $\mathrm{Eh}$ of $-76.5 \mathrm{mV}$ and therefore was anoxic or anaerobic, suggesting that nonresidual $\mathrm{Tl}$ and $\mathrm{Be}$ more readily combined organic matters, but not Fe or Mn oxides, in the sediments of the Nansihu Lake.

\subsection{Assessment of sediment contamination}

\subsubsection{Risk assessment code}

RAC was proposed on the basis of different binding forces of different forms of metal elements in the sediments. This method regarded carbonate bound and ion exchangeable (F1) as the effective parts of 

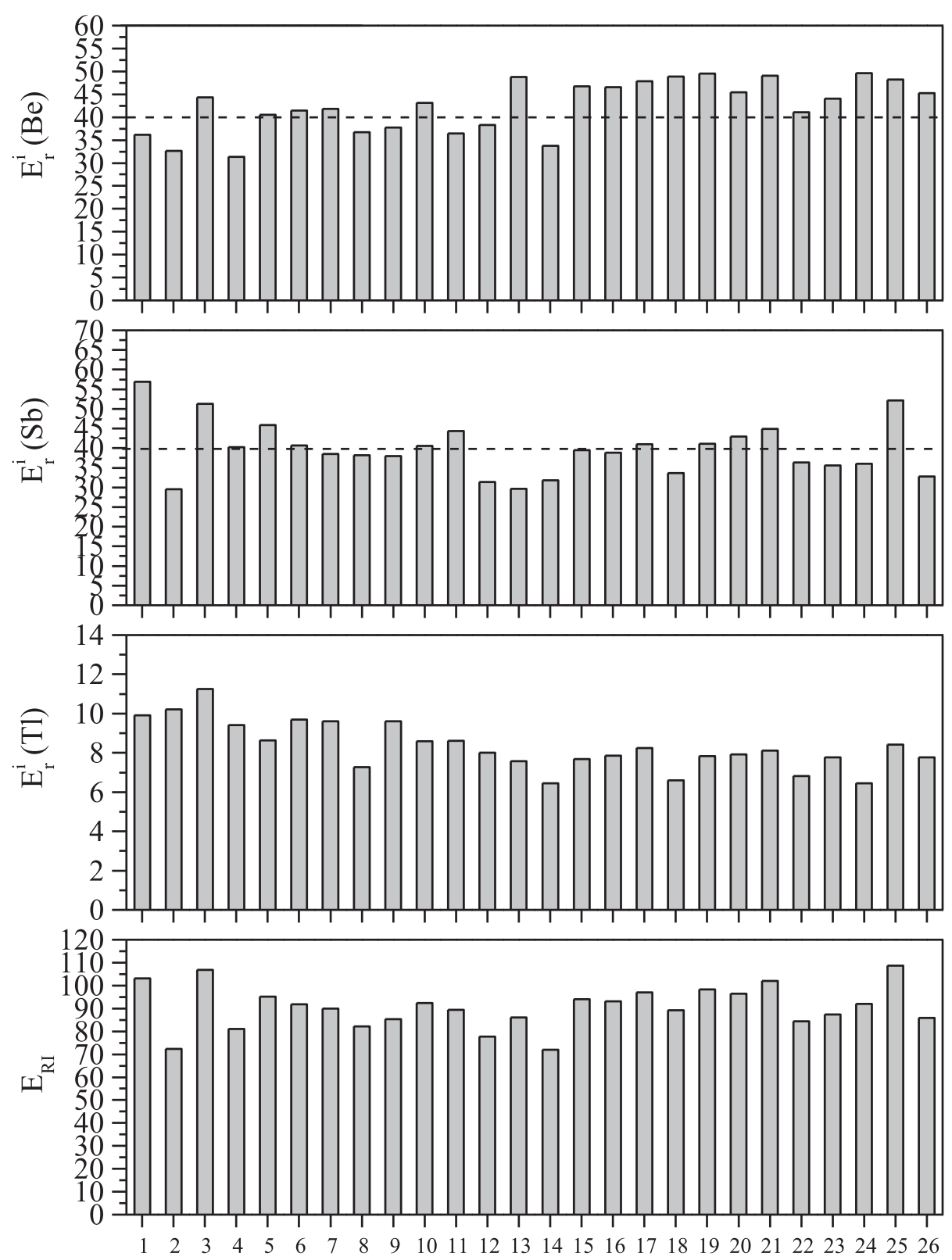

Site ID

Fig. 4. The spatial distributions of $E_{r}{ }^{i}$ and $E_{R I}$ values for the studied metals in the surface sediments.

Table 5

Rotated component matrix for data of metals and other parameters in sediment from the Nansihu Lake.

\begin{tabular}{lll}
\hline & PC1 & PC2 \\
\hline $\mathrm{Be}$ & -0.763 & 0.453 \\
$\mathrm{Sb}$ & 0.178 & 0.779 \\
$\mathrm{Tl}$ & 0.696 & 0.469 \\
$\mathrm{Al}$ & 0.915 & -0.007 \\
$\mathrm{Fe}$ & 0.796 & 0.387 \\
$\mathrm{Mn}$ & 0.794 & 0.413 \\
$\mathrm{Cr}$ & 0.629 & 0.536 \\
$\mathrm{Cu}$ & 0.014 & 0.918 \\
$\mathrm{Ni}$ & 0.26 & 0.927 \\
$\mathrm{~Pb}$ & 0.837 & 0.385 \\
$\mathrm{Zn}$ & 0.551 & 0.71 \\
Eigenvalue & 3.666 & 3.993 \\
$\%$ Total variance & 42.420 & 36.304 \\
$\%$ Cumulative variance & 42.420 & 78.724 \\
\hline
\end{tabular}

metal. The metal bioavailability in the sediments was evaluated by calculating F1 in total metal content to further evaluate the environmental risk. Higher the metal bioavailability, higher the environmental risk was, and vice versa.

RAC analysis results are shown in Fig. 3. Total Be content was the highest, 1.7 times the environmental background value, but F1 content was between $0.601 \%$ and $8.29 \%$, only $4.81 \%$ on average, indicating only low ecological risk. Total average Sb content was 2 times the environmental background value, and F1 content was between $3.85 \%$ and $20.59 \%, 7.03 \%$ on average. Most sampling sites had RAC of Sb between $1 \%$ and $10 \%$, indicating low environmental risk, whereas Sites 2,4 , and 9 had RAC of Sb of $20.59 \%, 17.00 \%$, and $10.653 \%$, respectively, indicating moderate risk. Total $\mathrm{Tl}$ content did not exceed the environmental background value, but RAC was between $0.73 \%$ and $2.58 \%$, $1.33 \%$ on average, indicating a potential risk, but a low risk level as a whole.

On the whole, RAC analysis results showed that Sb had the highest environmental risk, followed by $\mathrm{Be}$, and $\mathrm{Tl}$ had the lowest 

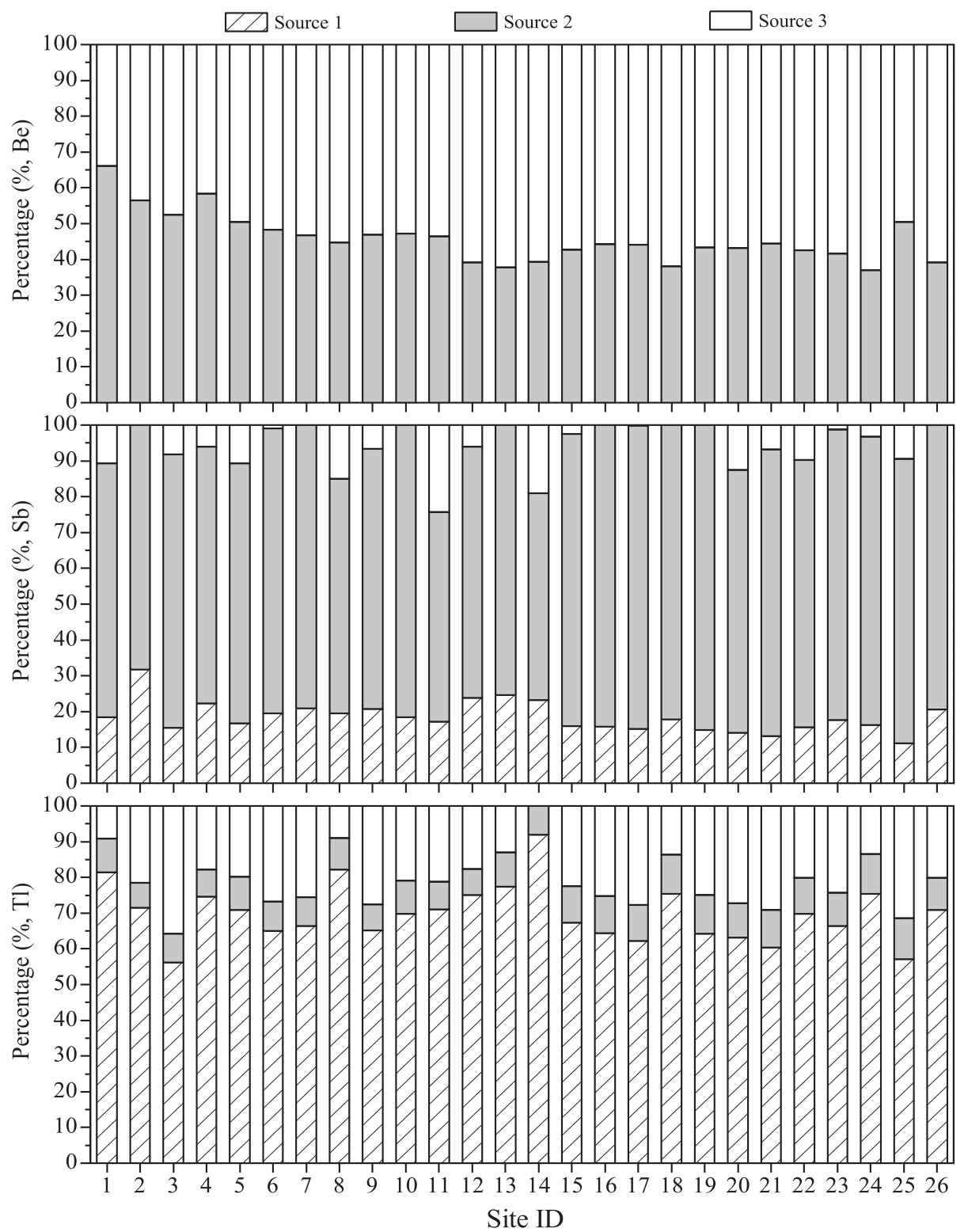

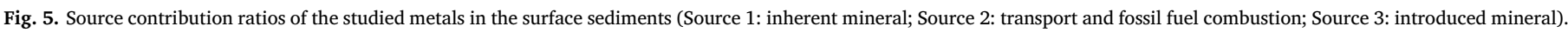

environmental risk.

\subsubsection{Potential ecological risk index}

The $\mathrm{E}_{\mathrm{r}}{ }^{\mathrm{i}}$ and $\mathrm{E}_{\mathrm{RI}}$ analysis results of $\mathrm{Be}, \mathrm{Sb}$, and $\mathrm{Tl}$ of the studied area are shown in Fig. 4. Be, Sb, and $\mathrm{Tl}$ had $\mathrm{E}_{\mathrm{r}}{ }^{\mathrm{i}}$ values of 31.36-49.63, 29.53-56.95, and 6.44-11.24, and average of 42.52, 39.69, and 8.32, respectively. $\mathrm{Tl}$ in all the sampling sites had $\mathrm{E}_{\mathrm{r}}{ }^{\mathrm{i}}$ values much less than 40 , indicating very low probability of ecological risk. For Be, only 4 of the total 9 sites in the lower section of the lake had $\mathrm{E}_{\mathrm{r}}{ }^{\mathrm{i}}$ values higher than 40 , reaching moderate ecological risk, while only 3 of 17 sites in the upper section of the lake had the $\mathrm{E}_{\mathrm{r}}{ }^{\mathrm{i}}$ values lower than 40 , and the others had $\mathrm{E}_{\mathrm{r}}^{\mathrm{i}}$ values higher than 40 , reaching moderate ecological risk. Different from Be, about half of the sites in the upper and lower sections of the lake had $\mathrm{E}_{\mathrm{r}}{ }^{\mathrm{i}}$ values higher than 40 for $\mathrm{Sb}$, reaching moderate ecological risk.

Coal development and utilization was the primary source of Be and Sb pollution in environment (Bai et al., 2004; Hulo et al., 2016; He and Wan, 2004; Cai et al., 2016). Thus, the industries of metallurgy, mining, thermal power generation, etc., in Jining, Zhaozhuang, Xuzhou, etc., around the Nansihu Lake were the sources of $\mathrm{Be}$ and $\mathrm{Sb}$ in environment.
However, Sb was a long-spreading global pollutant (Cloy et al., 2005; Shotyk et al., 2005; Krachler, et al., 2005). Thus, Sb in the sediments of the Nansihu Lake was mainly from air settlement in addition to minerals. This was an important reason for the significantly different distribution characteristics of Sb compared to Be in the lake.

$\mathrm{E}_{\mathrm{RI}}$ was an ecological risk evaluation method to comprehensively consider the ecological hazards of metal elements in sediments. Be, $\mathrm{Sb}$, and $\mathrm{Tl}$ in the surface sediments in the studied area had $\mathrm{E}_{\mathrm{RI}}$ values between 72.05 and 108.73, much lower than the minimum risk threshold, 150 , resulting in very low probability of combined ecological risk.

\subsubsection{Multiparameter evaluation index}

Before assessing ecological risks by MPE index, principal component analysis (PCA) was performed first to determine the human activity source of the PCs. According to relevant calculation results of receptor model for APCS/MLR, the contribution of human activity source to Be, $\mathrm{Sb}$, and $\mathrm{Tl}$ in sediments was determined.

The PCs were mainly obtained by selecting the variant with the characteristic root $>1$. The KMO test and the Bartlett's test were first performed for the data to be analyzed. The KMO test coefficient $>0.5$ 

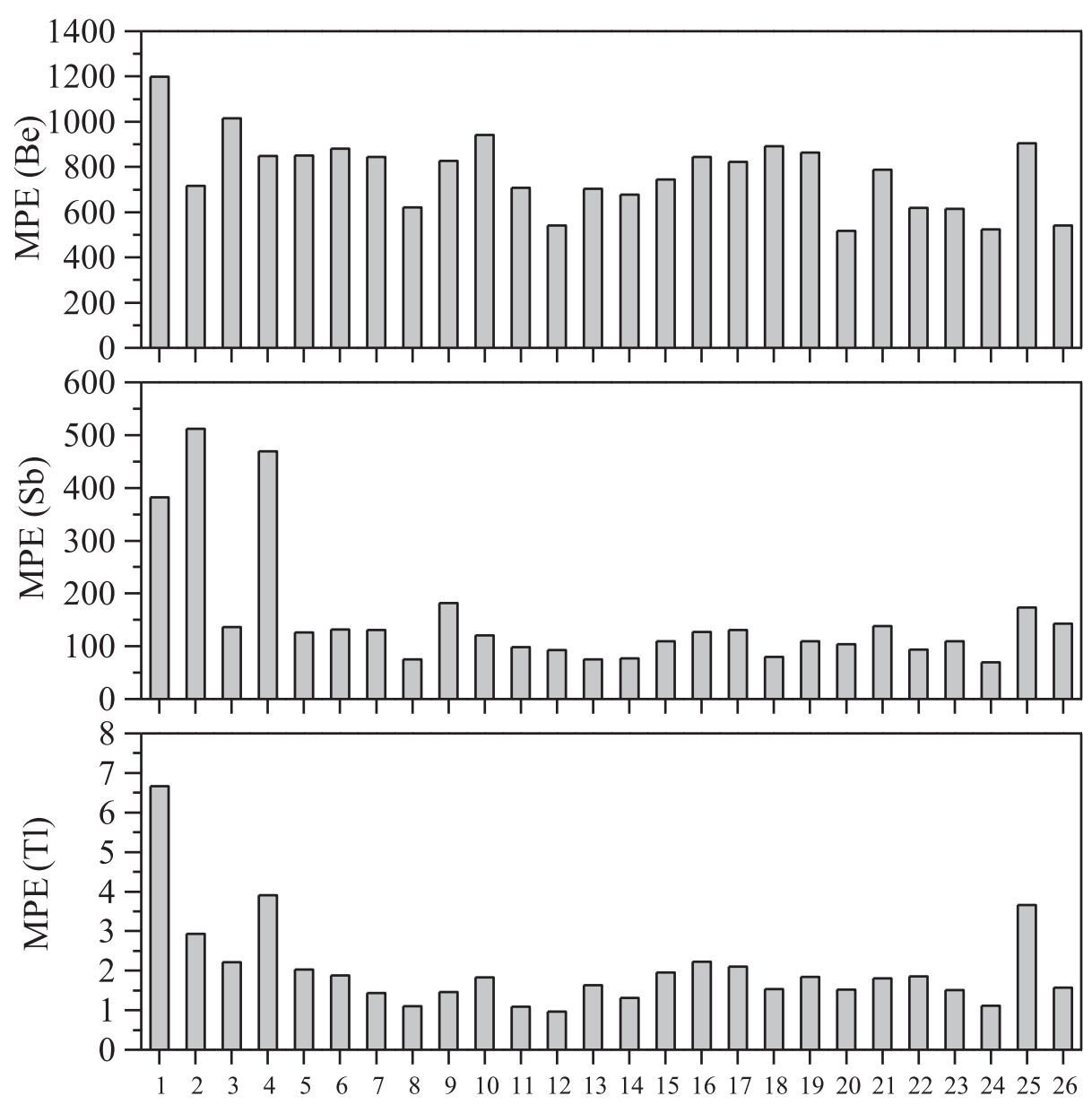

Site ID

Fig. 6. The spatial distributions of MPE values for the studied metals in the surface sediments.

and $\mathrm{P}$ value $<0.05$ indicated that the normalized data were suitable for PCA. PCA was conducted to analyze the association of Be, Sb, and Tl with $\mathrm{Al}, \mathrm{Fe}, \mathrm{Mn}, \mathrm{Cr}, \mathrm{Cu}, \mathrm{Ni}, \mathrm{Pb}$, and $\mathrm{Zn}$ (Table 5). This paper did not focus on heavy metals such as $\mathrm{Cr}, \mathrm{Cu}, \mathrm{Ni}, \mathrm{Pb}$, and $\mathrm{Zn}$; hence, their contents were used only for reference to analyze $\mathrm{Be}, \mathrm{Sb}$, and $\mathrm{Tl}$ sources and are listed in Appendix 1. Two common PCs were extracted to explain a sum of $78.72 \%$ of the total variance, among which $42.42 \%$ and $36.30 \%$ could be explained by PC1 and PC2, respectively.

PC1 had high Al, Fe, and Mn loads, which were indicators of natural sources (Duan et al., 2010; Qiao et al., 2013). Therefore, PC1 represents the natural source component of $\mathrm{Be}, \mathrm{Sb}$, and Tl. Although the previous speciation analysis results showed high residual Be content, it was concluded that Be was not formed naturally in the Nansihu Lake because of its high negative load in PC1. According to the above mentioned, Be content was much higher than the background value, and mining usually was the important source of Be in environment. Surrounding cities such as Jining, Tengzhou, and Zaozhuang are traditional coal-producing areas. Thus, $\mathrm{PC} 1$ represented $\mathrm{Be}, \mathrm{Sb}$, and $\mathrm{Tl}$ from natural sources. Be was mainly from introduced mineral.

PC2 had low Al, Fe, and Mn loads, especially the Al load being a negative value. Boat repair, vessel painting, transport, and others were the important sources of heavy metals such as $\mathrm{Cu}, \mathrm{Zn}$, and $\mathrm{Ni}$ in environment; PC2 had high Cu, Zn, and Ni loads (Zhang et al., 2013; Jain, 2004; Turner, 2010). As mentioned above, fossil fuel combustion is the important source of Sb in environment. Thus, PC2 represented sources of human activity such as transport and air settlement including fossil fuel combustion.

According to the above-mentioned method, two component scores for component analysis were converted to absolute component scores, which were used along with the content of each element for MLR to obtain MLR equation of each element and two absolute component score. Finally, the contribution rates of the two sources of $\mathrm{Be}, \mathrm{Sb}$, and $\mathrm{Tl}$ were calculated. MLR equation had the degrees of fitting $>80 \%$, and $p$ values $<0.01$, showing this model had high confidence.

The PCA method was used to obtain the Be, Sb, and Tl contributions from nature and human activities in sediments of the Nansihu Lake. However, according to the results of the receptor model, there were other sources that could not be explained by PCA in addition to the above two sources. Be was mainly from introduced mineral as mentioned above. Thus, other sources were included under natural sources. The contributions of $\mathrm{Be}, \mathrm{Sb}$, and $\mathrm{Tl}$ from all the sources in the sedimentsofthe Nansihu Lake are shown in Fig. 5.

The MPE values of $\mathrm{Be}, \mathrm{Sb}$, and $\mathrm{Tl}$ in each site were calculated, as shown in Fig. 6, according to the previously calculated toxicity coefficients of $\mathrm{Be}, \mathrm{Sb}$, and $\mathrm{Tl}$, contribution rates of human activities, and nonresidual contents. The MPE values of Be were between 517.26 and 1198.52, averagely 770.85; the MPE values of Sb were between 69.21 and 512.22, averagely 153.71; the MPE values of $\mathrm{Tl}$ were between 0.97 and 6.67, averagely 2.04. Be had 5 and 588 times higher average ecological risk than $\mathrm{Sb}$ and $\mathrm{Tl}$, respectively. Sb had 75 times higher average ecological risk than $\mathrm{Tl}$.

The average $\mathrm{F} 1$ contents of $\mathrm{Be}, \mathrm{Sb}$, and $\mathrm{Tl}$ were about $4.8 \%, 7 \%$, and $1.3 \%$, respectively. Hence, RAC analysis results showed that $\mathrm{Sb}$ had the highest ecological risk, followed by Be and Tl. In fact, the absolute content and percentage of the F1 form of Be were both much higher than that of Sb. But only the percentage (not the absolute content) of F1 
was used in RAC, and this was not strict. In addition, different elements had different toxicities, i.e., different toxicity coefficient value, for the same concentration of different elements; higher the toxicity coefficient, higher the ecological risk level was.

$\mathrm{Be}, \mathrm{Sb}$, and $\mathrm{Tl}$ had average $\mathrm{E}_{\mathrm{r}}{ }^{\mathrm{i}}$ values of $42.52,39.69$, and 8.32, respectively; hence, the ecological risk degree was $\mathrm{Be}>\mathrm{Sb}>\mathrm{Tl}$. These results contradicted those of RAC analysis. Usually, only nonresidual metal elements had stronger biotoxicity, and it was believed that residual metal elements had no potential ecological risk. Except RAC, speciation was neglected in common ecological risk-assessment methods. Therefore, there are obvious defects in both RAC and RI.

In addition to speciation and toxicity coefficient, the metal elements in water body during human activities were generally active and easily biologically reusable, resulting in ecological risk. Comprehensive consideration of the three factors enhanced the ecological risk assessment result. Thus, MPE could more intuitively distinguish the ecological risk levels of different elements than RAC and RI and more easily distinguish the ecological risk level of one element in different sampling areas. However, no value of toxicity graded by MPE was given in this paper because of lack of relevant experimental data. Only a reference method was provided for the researchers in relevant fields.

\section{Conclusions}

In this paper, a new metal element ecological risk-assessment method, referred to as multiparameter evaluation index (MPE), was created by a combination of receptor model, metal element speciation characteristics in sediments, and metal element toxicity coefficient.
Results of the macroanalysis showed that Be and Sb contents in sediments of the Nansihu Lake were obviously higher than the environmental background values, $\mathrm{Tl}$ contents were a little lower than the background value. Source apportionment indicated that Be was mainly from sources of human activities and exogenous minerals. Sb was mainly from human activities in addition to endogenetic minerals, and exogenous mineral sources only contributed a low proportion. Atmospheric deposition was the main way of access for exogenous $\mathrm{Sb}$ into the Nansihu Lake. Tl was mainly from endogenetic minerals followed by exogenous mineral, and human activities sources contributed a very low proportion. The results of MPE showed the ecological risk degree of the three metalswere in the following order: $\mathrm{Be}>\mathrm{Sb} \gg \mathrm{Tl}$, which was highly consistent with the results obtained by the other risk assessment methods. The research results showed that this index could more effectively distinguish the ecological risk level of different elements in sediments and more easily distinguish the ecological risk level of one element in different sampling areas than traditional assessment indices such as RI and RAC. This method could also be used for other water sediments or soil.

\section{Acknowledgements}

This study was co-supported by the Natural Science Foundation of Shandong Province, China (ZR2017QD012 and ZR2014DP005), the Innovative Training Program for College Students of China (201610904148 and 201710904118), and the National Natural Science Foundation of China (31600080). We also appreciate editors and anonymous referees for their excellent work.

\section{Appendices}

Appendix 1

Contents of macroelements and heavy metals in the surface sediment of the Nansihu Lake.

\begin{tabular}{|c|c|c|c|c|c|c|c|c|}
\hline Site & $\begin{array}{l}\mathrm{Al} \\
\mathrm{mg} / \mathrm{g}\end{array}$ & $\begin{array}{l}\mathrm{Fe} \\
\mathrm{mg} / \mathrm{g}\end{array}$ & $\begin{array}{l}\mathrm{Mn} \\
\mathrm{mg} / \mathrm{g}\end{array}$ & $\begin{array}{l}\mathrm{Cr} \\
\mu \mathrm{g} / \mathrm{g}\end{array}$ & $\begin{array}{l}\mathrm{Cu} \\
\mu \mathrm{g} / \mathrm{g}\end{array}$ & $\begin{array}{l}\mathrm{Ni} \\
\mu \mathrm{g} / \mathrm{g}\end{array}$ & $\begin{array}{l}\mathrm{Pb} \\
\mu \mathrm{g} / \mathrm{g}\end{array}$ & $\begin{array}{l}\mathrm{Zn} \\
\mu \mathrm{g} / \mathrm{g}\end{array}$ \\
\hline 1 & 71.07 & 50.99 & 1.92 & 127.04 & 31.50 & 57.54 & 46.65 & 124.52 \\
\hline 2 & 70.84 & 39.97 & 0.89 & 99.63 & 29.23 & 46.56 & 26.42 & 112.84 \\
\hline 3 & 68.05 & 40.79 & 0.92 & 96.53 & 35.12 & 53.09 & 17.29 & 102.15 \\
\hline 4 & 67.86 & 36.54 & 0.88 & 90.48 & 28.33 & 42.97 & 24.92 & 108.36 \\
\hline 5 & 58.89 & 38.73 & 0.73 & 97.14 & 30.11 & 46.49 & 14.08 & 94.79 \\
\hline 6 & 59.34 & 37.36 & 0.88 & 98.01 & 28.92 & 46.66 & 15.83 & 90.56 \\
\hline 7 & 60.99 & 38.33 & 0.95 & 95.37 & 27.66 & 46.20 & 15.34 & 90.79 \\
\hline 8 & 52.87 & 33.24 & 0.50 & 81.39 & 23.63 & 35.97 & 12.71 & 84.36 \\
\hline 9 & 60.34 & 34.20 & 0.60 & 84.10 & 26.80 & 40.36 & 14.62 & 82.34 \\
\hline 10 & 58.56 & 39.17 & 0.88 & 91.86 & 32.42 & 45.63 & 13.49 & 87.71 \\
\hline 11 & 57.06 & 31.90 & 0.70 & 78.16 & 23.73 & 37.91 & 13.69 & 71.91 \\
\hline 12 & 57.05 & 30.57 & 0.57 & 76.49 & 21.67 & 35.12 & 11.40 & 61.92 \\
\hline 13 & 63.57 & 39.86 & 0.81 & 89.51 & 28.13 & 43.71 & 12.98 & 69.37 \\
\hline 14 & 49.74 & 29.20 & 0.65 & 72.15 & 18.71 & 30.50 & 7.26 & 56.33 \\
\hline 15 & 38.38 & 30.99 & 0.81 & 79.72 & 29.34 & 44.26 & 10.71 & 79.89 \\
\hline 16 & 37.47 & 31.11 & 0.67 & 77.60 & 31.89 & 46.07 & 10.80 & 84.02 \\
\hline 17 & 40.95 & 30.76 & 0.68 & 80.15 & 30.60 & 48.21 & 11.37 & 91.33 \\
\hline 18 & 37.08 & 34.65 & 0.34 & 89.17 & 27.23 & 40.86 & 8.55 & 63.07 \\
\hline 19 & 36.59 & 33.24 & 0.71 & 87.73 & 31.97 & 47.43 & 11.30 & 81.74 \\
\hline 20 & 34.55 & 26.83 & 0.60 & 75.15 & 27.83 & 42.87 & 10.72 & 77.99 \\
\hline 21 & 39.41 & 30.64 & 0.46 & 82.75 & 31.89 & 48.26 & 11.07 & 86.77 \\
\hline 22 & 22.08 & 18.44 & 0.30 & 78.96 & 24.07 & 38.49 & 9.57 & 74.10 \\
\hline 23 & 33.01 & 24.34 & 0.57 & 85.29 & 24.27 & 42.67 & 10.38 & 74.54 \\
\hline 24 & 36.55 & 26.45 & 0.29 & 94.82 & 22.62 & 41.37 & 8.88 & 69.36 \\
\hline 25 & 35.50 & 28.85 & 0.50 & 90.89 & 39.33 & 48.04 & 13.40 & 113.24 \\
\hline 26 & 50.06 & 26.95 & 0.43 & 93.39 & 22.55 & 43.07 & 11.68 & 74.43 \\
\hline
\end{tabular}


Appendix 2

The coordinates of the sampling sites in the Nansihu Lake.

\begin{tabular}{|c|c|c|c|c|c|}
\hline Site & Longitude (E) & Latitude (N) & Site & Longitude (E) & Latitude $(\mathrm{N})$ \\
\hline 1 & 117.361871 & 34.595985 & 14 & 116.780488 & 35.043775 \\
\hline 2 & 117.277765 & 34.622511 & 15 & 116.729867 & 35.063945 \\
\hline 3 & 117.237345 & 34.458190 & 16 & 116.699368 & 35.079535 \\
\hline 4 & 117.266913 & 34.640493 & 17 & 116.692732 & 35.084353 \\
\hline 5 & 117.220900 & 34.688347 & 18 & 116.700633 & 35.100710 \\
\hline 6 & 117.181417 & 34.701417 & 19 & 116.691625 & 35.090498 \\
\hline 7 & 117.157840 & 34.710238 & 20 & 116.662097 & 35.130970 \\
\hline 8 & 117.071500 & 34.808917 & 21 & 116.649875 & 35.193003 \\
\hline 9 & 117.014482 & 34.852383 & 22 & 116.617833 & 35.239595 \\
\hline 10 & 116.923805 & 34.942402 & 23 & 116.652790 & 35.197493 \\
\hline 11 & 116.947450 & 34.914198 & 24 & 116.598643 & 35.260378 \\
\hline 12 & 116.882168 & 35.000642 & 25 & 116.608026 & 35.251622 \\
\hline 13 & 116.847160 & 35.036638 & 26 & 116.614351 & 35.235917 \\
\hline
\end{tabular}

\section{References}

Alexander, C.R., Smith, R.G., Calder, F.D., Schropp, S.J., Windom, H.L., 1993. The historical record of metal enrichments in two Florida estuaries. Estuaries 16, 627-637.

Antoine, P., Muhammad, S., Nathalie, S.D., Camille, D., 2015. Antimony bioavailability: knowledge and research perspectives for sustainable agricultures. J. Hazard. Mater 289, 219-234.

Bai, X.F., Li, W.H., Chen, W.M., 2004. Distribution and modes of occurrence of beryllium in Chinese coals. J. Fuel Chem. Technol. 32 (2), 155-159 (In Chinese with English abstract).

Cai, F., Ren, J.H., Tao, S., Wang, X.L., 2016. Uptake, translocation and transformation of antimony in rice (Oryza sativa L.) seedlings. Environ. Pollut. 209, 169-176.

Chen, J.S., Wang, Z., Liu, Y.J., 1989. Potential risk of heavy metal pollution in water: assessment by sedimentology measure. Environ. Sci. Technol. 9, 16-25 (In Chinese)

Cleven, R., Fokkert, L., 1994. Potentiometric stripping analysis of thallium in naturalwaters. Anal. Chim. Acta 289, 215-221.

Ciblin, A.E., 1997. Benthic metabolism and nutrient cycling in Boston Harbon, Massachusetts. Estuaries 20, 346-364.

Cloy, J.M., Farmer, J.G., Graham, M.C., Mackenzie, A.B., Cook, G.T., 2005. A comparison of antimony and lead profiles over the past 2500 years in Flanders Moss ombrotrophic peat bog, Scotland. J. Environ. Monitor. 7 (12), 1137-1147.

Dong, X.J., 2009. Annals of Weishan County 1991-2005. Shandong Pictorial Publishing House, Jinan, pp. 54-60 (In Chinese).

Duan, L.Q., Song, J.M., Xu, Y.Y., Li, X.G., Zhang, Y., 2010. The distribution, enrichment and source of potential harmful elements in surface sediments of Bohai Bay, North China. J. Hazard. Mater. 183, 155-164.

Filella, M., Belzile, N., Chen, Y.W., 2002. Antimony in the environment: a review focused on natural waters: I. Occurrence. Earth-Sci. Rev. 57 (1-2), 125-176.

Fort, M., Grimalt, G.O., Querol, X., Casas, M., Sunyer, J., 2016. Evaluation of atmospheric inputs as possible sources of antimony in pregnant women from urban areas. Sci. Total Environ. 544, 391-399.

Gao, X.L., Chen, C.T.A., Wang, G., Xue, Q.Z., Tang, C., Chen, S.Y., 2010. Environmental status of Daya Bay surface sediments inferred from a sequential extraction technique. Estuar. Coast. Shelf Sci. 86, 369-378.

Guo, Y.S., 1990. The historical change of lakes in Shandong Province. T. Oceanol. Limnol. 3, 15-22 (In Chinese with English abstract).

Håkanson, L., 1980. An ecological risk index for aquatic pollution control. A sedimentological approach. Water Res. 14, 975-1001.

Harter, R.D., 1968. Adsorption of phosphorus by lake sediments. Soil Sci. Soc. Am. J. 32 (4), 514-518

He, M.C., Wan, H.Y., 2004. Distribution, speciation, toxicity and bioavailability of antimony in the environment. Prog. Chem. 16 (1), 131-135 (In Chinese with English abstract).

Thurston, G.D., Spengler, J.D., 1985. A multivariate assessment of meteorological influences on inhalable particle source impacts. J Appl. Meteorol. Clim. 24 (11), 1245-1257.

Hulo, S., Radauceanu, A., Chérot-Kornobis, N., Howsam, M., Vacchin, V., De Broucker, V., Rousset, D., Grzebyk, M., Dziurla, M., Sobaszek, A., Edme, J.L., 2016. Beryllium in exhaled breath condensate as a biomarker of occupational exposure in a primary aluminum production plant. Int. J. Hyg. Environ. Health 219 (1), 40-47.

Jain, C.K., 2004. Metal fractionation study on bed sediments of River Yamuna, India. Water Res. 38, 569-578.

Karbassi, A.R., Shankar, R., 2005. Geochemistry of two sediment cores from the west coast of India. Int. J. Environ. Sci. Technol. 1, 307-316.

Kenneth, A., Walsh, E., Dalder, A., Goldberg D., Olson, L., 2009. Beryllium Chemistry and Processing. http:/www openisbn.com/isbn/0871707217/.

Krachler, M., Zheng, J., Koerner, R., Zdanowicz, C., Fisher, D., Shotyk, W., 2005. Increasing atmospheric antimony contamination in the northern hemisphere: snow and ice evidence from Devon Island, Arctic Canada. J. Environ. Monitor. 7 (12), $1169-1176$.

Li, S., Zhang, Z.L., 2012. Spatial distribution and pollution assessment of heavy metals in surface sediments of Nansihu Lake. Water Resour. Protect. 28 (4), 6-11 (In Chinese with English abstract).

Lu, M.S., Kong, F.S., Zhuang, X.H., 2003. Comprehensive environmental-geological survey of the Nansi Lake drainage area, southwestern Shandong. Geol. China 30 (4), 424-428 (In Chinese with English abstract).

Ma, Z.D., Gao, H., Yang, J., Xi, J.C., Li, X.M., Ge, Q.S., 2014. Valuation of Nansihu Lake wetland ecosystem services based on multi-sources data fusion. Resour. Sci. 6 (4) 840-847 (In Chinese with English abstract).

Mou, B.L., 1999. Geochemistry of Elements. Beijing University Press, Beijing, pp. 152-156 (In Chinese with English abstract).

Müller, G., 1969. Index of geoaccumulation in sediments of the Rhine River. Geojournal 2, 108-118.

Perin, G., Craboledda, L., Lucchese, L., Cirillo, R., Dotta, L., Orio, A.A., 1985. Heavy metal speciation in the sediments of Northern Adriatic Sea: a new approach for environmental toxicity determination. In: Lekkas, T.D. (Ed.), Heavy Metal in the Environment. CEP Consultant, Edinburgh 2, pp. 454-456.

Peter, A.L.J., Viraraghavan, T., 2005. Thallium: a review of public health and environmental concerns. Environ. Int. 31, 493-501.

Prica, M., Dalmacija, B., Rončević, S., Krčmar, D., Bečelić, M., 2008. A comparison of sediment quality results with acid volatile sulfide (AVS) and simultaneously extracted metals (SEM) ratio in Vojvodina (Serbia) sediments. Sci. Total. Environ. 389, 235-244.

Qiao, Y.M., Yang, Y., Gu, J.G., Zhao, J.G., 2013. Distribution and geochemical speciation of heavy metals in sediments from coastal area suffered rapid urbanization, a case study of Shantou Bay, China. Mar. Pollut. Bull. 68, 140-146.

Qi, W.Q., Chen, Y.L., Cao, J.S., 1992. Indium and thallium background contents in soils in China. Int. J. Environ. Stud. 23, 31-33.

Rauret, G., López-Sánche, J.F., Sahuquillo, A., Rubio, R., Davidson, C., Ure, A., Quevauviller, P., 1999. Improvement of the BCR three step sequential extraction procedure prior to the certification of new sediment and soil reference materials. J. Environ. Monitor. 1, 57-61.

Schoer, J., 1984. Thallium. In: Hutzinger, O. (Ed.), The Handbook of Environmental Chemistry V (3) Part C. Springer-Verlag, New York 3 (c), pp. 143-214.

Shotyk, W., Chen, B., Krachler, M., 2005. Lithogenic, oceanic and anthropogenic sources of atmospheric Sb to a maritime blanket bog, Myrarnar, Faroe Islands. J. Environ. Monitor. 7 (12), 1148-1154.

Slobodan, R., Jankovic, S., Belgrade, J., 1993. Metallogenic features of the Alsar epithermal Sb-As-Tl-Au deposit (the Serbo-Macedonian metallogenic province). Int. Geol. Rev. 35, 121-145.

Sun, W.S., Dong, X.H., 1991. The study of beryllium element background value in soil. Res. Environ. Sci. 4 (6), 13-17 (In Chinese with English abstract).

Taylor, S.R., McLennan, S.M., 1995. The geochemical evolution of the continental crust. Rev. Geophys. 33, 241-265.

Tech, I.T., 1986. Development of Sediment Quality Values For Puget Sound. Volume 1. Puget Sound Dredged Disposal Analysis Report. Tetra Tech Incorporated.

Turner, A., 2010. Marine pollution from antifouling paint particles. Mar. Pollut. Bull. 60, $159-171$.

USEPA, 1979. Water Related Fate of The 129 Priority Pollutants. Washington, DC, USA.

Wappelhorst, O., Kühn, I., Oehlmann, J., Markert, B., 2000. Deposition and disease: a moss monitoring project as an approach to ascertaining potential connections. Sci. Total Environ. 249, 243-256.

Wu, F.C., Zheng, J., Pan, X.L., Li, W., Deng, Q.J., Mo, C.L., Zhu, J., Liu, B.J., Shao, S.X., Guo, J.Y., 2008. Prospect on biogeochemical cycle and environmental effect of antimony. Adv. Earth Sci. 23 (4), 350-356 (In Chinese with English abstract).

Xu, Z.Q., Ni, S.J., Tuo, X.G., Zhang, C.J., 2008. Calculation of heavy metals' toxicity coefficient in the evaluation of potential ecological risk index. Environ. Sci. Technol. 31, 112-115 (In Chinese with English abstract).

Yang, L.Y., Shen, J., Zhang, Z.L., Zhu, Y.X., Sun, Y., 2003. Multivariate analysis of heavy metal and nutrient in surface sediments of Nansihu Lake, China. Environ. Sci. 23 (2), 206-209 (In Chinese with English abstract).

Yang, Y.Q., Chen, F.R., Zhang, L., Liu, J.S., Wu, S.J., Kang, M.L., 2012. Comprehensive assessment of heavy metal contamination in sediment of the Pearl River Estuary and adjacent shelf. Mar. Pollut. Bull. 64, 1947-1955.

Zhang, B., Zhang, Z., Zhang, X., Chen, G.A., 1997. Research into environmental 
geochemistry of lanmuchang thallium deposit in Xingren of Guizhou Province. Guizhou Geol. 14 (1997), 71-78 (In Chinese with English abstract).

Zhang, R., Zhou, L., Zhang, F., Ding, Y.J., Gao, J.R., Chen, J., Yan, H.Q., Shao, W., 2013. Heavy metal pollution and assessment in the tidal flat sediments of Haizhou Bay, China. Mar. Pollut. Bull. 74, 403-412.

Zhang, Y.X., Sun, J.C., Hang, G.X., Liu, J.T., Jing, J.H., Xiang, X.P., Chen, X., Wang, J.P., Cui, H.W., 2011. Distribution of beryllium in shallow groundwater of the Zhujiang Delta and a preliminary analysis of its origin. Geol. China 38 (1), 197-203 (In Chinese with English abstract).

Zhao, Y.Y., Yan, M.C., 1992. Comparison of chemical element abundances in sediments of the Yellow River, the Changjiang River and the shallow seas of China. Chin. Sci. Bull. 13, 1202-1204 (In Chinese).

Zhuang, W., Liu, Y.X., Chen, Q., Wang, Q., Zhou, F.X., 2016. A new index for assessing heavy metal contamination in sediments of the Beijing-Hangzhou Grand Canal (Zaozhuang Segment): a case study. Ecol. Indic. 69, 252-260.

Zhu, J., Guo, J.Y., Wang, L.Y., Pan, X.L., Fu, Z.Y., Liao, H.Q., Wu, F.C., 2010. Overview on research on environmentally geochemical characteristics of antimony. Earth Environ. 38 (1), 109-116 (In Chinese with English abstract).

Zhuang, W., 2016. Eco-environmental impact of inter-basin water transfer projects: a review. Environ. Sci. Pollut. R. 23 (13), 1-13. 